\title{
Spinal cord compression in thalassaemia
}

\author{
J. N. CROS S, O.S. MOR G A N,W. N. G I B B S , \\ A N D I. CHER U V A N K Y \\ From The University Hospital of the West Indies, Kingston, Jamaica
}

S UMMARY Two cases of spinal cord compression resulting from extramedullary haemopoiesis in patients with thalassaemia of intermediate clinical severity are reported. The association between mild thalassaemia with long survival and the risk of spinal cord compression from extramedullary haemopoietic deposits is emphasised.

Extramedullary haemopoiesis occurs in a variety of haematological and other disorders, the usual sites being the liver, spleen, and lymph nodes (Wintrobe, 1975). The onset of unexpected clinical signs may be the first indication that haemopoiesis is proceeding in atypical areas. Spinal cord compression is an unusual complication of extramedullary haemopoiesis and its development as a consequence of thalassaemia a rare event. To date only six such cases have been reported in the literature.

\section{Case reports}

\section{CASE 1}

A 25 year old black Jamaican woman (DW) presented at the University Hospital in 1954 with a history of sudden onset of leg pain and inability to walk for the previous 24 hours. She reported also patchy, variable, intermittent sensory depression in the leg which gradually improved over four days.

During the next seven years she was readmitted to hospital on three occasions with similar transient myelopathic episodes: on each occasion full recovery of sensation and power occurred within one week. In February 1961, during hospitalisation in the third trimester of pregnancy, she developed paraparesis. After delivery of the child by Caesarean section, myelography showed a spinal block at the level of the sixth thoracic vertebra, the appearances indicating an extradural mass. Laminectomy was performed and showed a vascular, soft, extradural mass at the indicated level. The bone marrow in the laminae was found to be haemopoietic, and the extradural mass showed the

Address for reprint requests: Professor J. N. Cross, Department of Surgery, University Hospital of the West Indies, Kingston, Jamaica. Accepted 18 July 1977 features of haemopoietic tissue. A course of radiation to the affected area of the spine was given postoperatively. Full recovery of sensation and motor function returned over the next three years when she was able to resume her occupation as a domestic helper. There have been no further episodes of paraparesis but in 1975 she was readmitted to the Hospital in a hypoplastic crisis with cardiac failure. Soft tissue masses were noted on a chest film taken at that time. Tomography showed the masses to lie around the anterior and posterior ends of the ribs, the marrow spaces of which were enlarged: the appearances were held to be consistent with extramedullary haemopoiesis. The haematological findings in this patient (Table 1) are indicative of B-thalassaemia with a clinical severity between that of Cooley's anaemia and Bthalassaemia trait.

The patient's mother and each of her children have the beta-thalassaemia trait.

\section{CASE 2}

A 44 year old Jamaican male (FT) of predominantly African ancestry was admitted to the University Hospital in 1966 for investigation of anaemia with exertional dyspnoea, left hypochondrial fullness, and recurrent leg ulceration. Examination showed marked hepatosplenomegaly, and haematological studies (Table 1) suggested a diagnosis of beta-thalassaemia, again of intermediate severity. Radiological studies of the bones showed features consistent with extramedullary haemopoiesis associated with a haemoglobinopathy.

Splenectomy and liver biopsy were performed; both organs showed marked haemopoiesis.

Nine years later the patient was readmitted with a four months history of low back pain, hesitancy on urination, and spastic paraparesis progressive to the point of inability to walk without assistance. 
Table 1 Haematological data

\begin{tabular}{|c|c|c|c|c|c|c|c|c|c|c|c|}
\hline $\begin{array}{l}\text { Case } \\
\text { number }\end{array}$ & $\begin{array}{l}\text { Age } \\
(y r)\end{array}$ & $\begin{array}{l}H b \\
g m / d l\end{array}$ & $\underset{\%}{H b / F}$ & $\begin{array}{l}H b / A \\
\%\end{array}$ & $\begin{array}{l}\mathrm{Hb} / \mathrm{A}_{2} \\
\%\end{array}$ & $\begin{array}{l}P C V \\
\%\end{array}$ & $\underset{\%}{M C H C}$ & $\begin{array}{l}\text { Reticulo- } \\
\text { cytes } \\
\%\end{array}$ & \multicolumn{3}{|c|}{$\begin{array}{l}\text { Serum iron studies } \\
\mu \mathrm{g} / \mathrm{dl}\end{array}$} \\
\hline \multirow{2}{*}{1} & & & & & & & & & $\begin{array}{l}\text { Serum Fe } \\
\text { UIBC }\end{array}$ & - & $\begin{array}{l}100 \\
154\end{array}$ \\
\hline & 44 & 9.0 & 93 & 2 & - & 30 & 30 & 2.8 & $\begin{array}{l}\text { TIBC } \\
\text { Saturation }\end{array}$ & - & $\begin{array}{r}254 \\
39 \%\end{array}$ \\
\hline
\end{tabular}

One month before admission he had developed burning paraesthesiae in the feet, and this had ascended to the level of the abdomen. The upper limbs and cranial nerves were not affected.

The positive findings were of weakness of the lower extremities (grade 4, MRC), hyperreflexia with bilateral Babinski responses, and absent abdominal reflexes. There was a partial sensory level to touch and pinprick at the level of the T8 dermatome; vibration sense was diminished bilaterally as high as the anterior superior iliac spines, and joint position sense was depressed in the left hallux but preserved in the right. The skeletal radiographic appearances were more widespread than on the first occasion, and myelography showed a spinal block at the level of the seventh thoracic vertebra, the appearances being consistent with an extradural mass.

Laminectomy showed infiltration of the vertebral arches with a dark, brownish-red tissue, breaking through the bone in several places and extending in cylindrical fashion along the spinal canal from the ninth to the fourth thoracic vertebra. The extradural mass was very vascular but could be separated from the dura mater with little difficulty, and extensive dorsolateral decompression of the theca was performed.

Histological examination of the perithecal tissue (IC) showed haemopoietic material containing all elements of erythropoiesis and myelopoiesis including megakaryocytes. The overall appearance resembled that of a sternal bone marrow biopsy.

A postoperative course of radiotherapy was given to the thoracic spinal column to forestall recurrence. Rapid improvement in the neurological signs followed operative decompression with conversion of the abnormal plantar responses and recovery of a normal gait within seven months.

\section{Discussion}

Routine investigation may suggest extramedullary haemopoiesis as the basis of spinal cord compression, particularly in patients with a haemoglobinopathy. When the extramedullary haemopoietic tissue, is found on radiographs, the characteristic appearance of well-circumscribed, lobular masses in the anterior and posterior mediastinum helps to differentiate the condition from other types of mediastinal tumours (Sorsdahl et al., 1964). Such an appearance in association with hepatosplenomegaly and bone changes indicative of a haemolytic process in a paraplegic, thalassaemic patient renders the diagnosis almost conclusive.

The diagnosis of B-thalassaemia previously described in the Jamaican negro (Went and MacIver, 1961; Ahern et al., 1975) was established in our cases on the basis of the peripheral blood picture, the high level of fetal haemoglobin, and the family history. These patients constitute examples of the mild type of thalassaemia seen in Jamaica where the incidence of the trait is $0.8 \%$ (Ahern et al., 1973). The occurrence of two such individuals with spinal cord compression from extramedullary haemopoiesis is surprising in view of the rarity of this complication as recorded in the literature. The previous episodes of rapidly recovering transverse myelopathy in our first case were most probably caused by temporary ischaemia of the cord resulting from obstruction of the microcirculation during lytic crises.

It is of interest to compare the ages of presentation of the Negro cases with those reported in people of Mediterranean ancestry (Table 2): in the latter group the condition presents at an earlier age. The older age at presentation of the Caribbean cases probably reflects the milder nature of the disease process in this area (Friedman et al.,

Table 2 Ages of patients by racial group

\begin{tabular}{lll}
\hline & Italian & Negro \\
\hline Male & 26 & 40 \\
& 21 & 47 \\
& & 42 \\
Female & & 53 \\
\hline Mean & 4 & 32 \\
\hline
\end{tabular}

$P<0.001$

Data from Luyendijk et al. (1975) and this report. 
1974), in comparison with the clinical pattern in the Mediterranean races where thalassaemia is typically associated with death in childhood (Conley, 1971).

It is intriguing to note that in Jamaica, where there is a high incidence of the sickle cell trait (Miall et al., 1967), there have been no cases of spinal cord compression resulting from extramedullary haemopoiesis associated with sickle cell anaemia. This accords with the findings of Adeloye and Odeku (1970) in Nigeria and, indeed, only one such case has been reported in the literature (Ammoumi et al., 1975). It is probable that the oxygen dissociation characteristics of the haemoglobin-S molecule, which results in good tissue oxygenation even with low haemoglobin levels, offers less of a stimulus to widespread extramedullary haemopoietic activity in sickle cell anaemia (Serjeant, 1974).

We agree with Luyendijk et al. (1975) that the chance of spinal cord compression developing in older patients with this relatively benign type of thalassaemia is not remote, particularly where splenectomy has been performed. We urge, therefore, that this possibility should be examined in any patient with such a haemoglobinopathy who presents with a transverse myelopathy.

\section{References}

Adeloye, A., and Odeku, E. L. (1970). The nervous system in sickle cell disease. African Journal of Medical Science, 1, 33-48.

Ahern, E., Herbert, R., MacIver, C., Ahern, V., Wardle, J., and Seakins, M. (1975). Beta-thalassaemia of clinical significance in adult Jamaican Negroes. British Journal of Haematology, 30, 197-213.

Ahern, E., Swan, A., and Ahern, V. (1973). The prevalence of the race-inherited haemoglobin defects in adult Jamaicans. British Journal of Haematology, 25, 437-444.

Ammoumi, A. A., Sher, J. H., and Schmelka, D. (1975). Spinal cond compression by extra-medullary hemopoietic tissue in sickle cell anemia. Case report. Journal of Neurosurgery, 43, 483-485.

Conley, C. (1971). The hemoglobinopathies and thalassemias. In Cecil-Loeb's Textbook of Medicine. Edited by P. B. Beeson and W. McDermott, 13th edition, p. 1504. W. B. Saunclers Company: Philadelphia.

Friedman, G. K., Schwartz, E., Ahern, V., and Ahern, E. (1974). Globin synthesis in the Jamaican Negro with B-thalassaemia. British Journal of Haematology, 28, 505-513.

Luyendijk, W., Went, L., and Schaad, H. D. J. (1975). Spinal cord compression due to extra-medullary hemopoiesis in homozygous thalassemia. Journal of Neurosurgery, 42, 212-216.

Miall, W. E., Milner, P. F., Lovell, H. G., and Standard, K. L. (1967). Haematological investigation of population samples in Jamaica. British Journal of Preventive and Social Medicine, 21, 45-55.

Serjeant, G. R. (1974). The Clinical Features of Sickle Cell Disease, p. 80. North-Holland Publishing Company: Amsterdam.

Sorsdahl, O. S., Taylor, P. E., and Noyes, W. N. (1964). Extra-medullary hematopoiesis, mediastinal masses and spinal cord compression. Journal of the American Medical Association, 189, 343-347.

Went, L. N., and MacIver, J. E. (1961). Thalassaemia in the West Indies. Blood, 17, 166-181.

Wintrobe, M. M. (1975). Clinical Hematology, 7th edition p. 59. Lea and Febiger: Philadelphia. 